\title{
The Pernicious Influence of Citizenship Rights on Workers' Rights in the EU - The Case of Student Finance
}

\author{
Araceli Turmo*
}

\section{Introduction}

The need to move beyond an understanding of EU citizenship as a component of freedom of movement within the internal market is emphasized throughout EU Citizenship and Federalism: The Role of Rights. As Dimitry Kochenov writes, EU citizenship cannot be restricted to such a role and must take on a different meaning if it is to fulfil its potential. ${ }^{1}$ However, this is not, as it often appears to be, only apparent in the case law related to 'inactive' or static Union citizens. The free movement of workers can also suffer from the current uncertainties through the insidious influence of integration tests initially applicable only outside the scope of Art. 45 TFEU. In that sense, it is not entirely true that the CJEU 'might reasonably now believe that it has done its job'2 in creating a single physical space in the Union through free movement rules. Such a statement does not take into account the potential for reversal in the rights associated with free movement within the internal market. Indeed, the absence of a true shift towards a new vision of citizenship and solidarity within the European Union can also produce unfortunate regressions in citizens' rights where they used to be most wellestablished.

* Maître de conférences, University of Nantes. I would like to thank in particular Professors Dimitry Kochenov and Eleftheria Neframi for inviting me to the conference in Luxembourg where an earlier version of this Article was presented, and the anonymous reviewers for their helpful comments.

1 Kochenov, D., On Tiles and Pillars: EU Citizenship as a Federal Denominator. In Kochenov, D., ed. (2017). EU Citizenship and Federalism: The Role of Rights. Cambridge: Cambridge University Press, pp. $3^{-81}$.

2 To borrow the phrase used in Sarmiento, D., Sharpston, E. (2017), European Citizenship and Its New Union: Time to Move On? In Kochenov, D., ed., EU Citizenship and Federalism, cit., pp. 226-242, p. 230. 
Since the early 200os, a limited, but noticeable trend of European Court of Justice (CJEU) case law has extended the application of the 'sufficient link of integration' test to the social advantages of workers exercising their free movement rights, more specifically frontier workers. The most problematic aspect of this case law concerns an admission of restrictions of the right of students to benefit from funding in the Member State where their parents work, under the same conditions as the children of nationals and migrant workers, in order to study in another Member State. ${ }^{3}$ This trend clearly clashes with the traditional approach to the free movement of workers, which under the fifth recital of Regulation $492 / 2011^{4}$ 'should be enjoyed without discrimination by permanent, seasonal and frontier workers'. This freedom includes the right to equal treatment concerning enjoyment of social advantages under Article 7(2) of the Regulation. Facing resistance from Member States, the Court of Justice has long confirmed that access to such social advantages should extend without discrimination to frontier workers. ${ }^{5}$ The Court had also ruled that the dependent child of a national of a Member State who is employed in another Member State as a frontier worker could rely on this provision in order to obtain study finance under the same conditions as the child of a national of the State of employment. ${ }^{6}$

Frontier workers have doubtless long been a problematic category in EU law. Although Article 45 TFEU and Regulation 492/2011 are, in principle, applicable to both migrant and frontier workers, granting the full benefit of the right to equal treatment to frontier workers had previously been perceived as less necessary or more questionable. ${ }^{7}$ Indeed, frontier workers often retain their residence in their State of origin ${ }^{8}$ and cannot truly be considered 'migrants', which means it is not as necessary to grant them advantages that

3 Court of Justice, judgment of 14 June 2012, case C-542/o9, Commission v. Netherlands; judgment of 20 June 2013, case C-20/12, Giersch e.a. v. Luxembourg; judgment of 14 December 2016, case C-238/15, Bragança Linares Verruga e.a.; judgment of ${ }_{15}$ December 2016, joined cases C-401 to 402/15, Depesme and Kerrou e.a.; judgment of 10 July 2019, case C-410/18, Nicolas Aubriet.

4 Regulation (EU) 492/2011 of the European Parliament and of the Council of 5 April 2011 on freedom of movement for workers within the Union.

5 Court of Justice, judgment of 27 November 1997, case C-57/96, Meints v. Minister van Landbouw, Natuurbeheer en Visserij, paras 49-50.

6 Court of Justice, judgment of 8 June 1999, case C-337/97, Meeusen v. Hoofddirectie van de Informatie Beheer Groep, para. 21 ss.

7 Iliopoulou, A. (2013). Le rattachement à l'Etat comme critère de l'intégration sociale. Revue des affaires européennes n. 4, pp. 651-666, 655 .

8 The ECJ has, however, held that EU citizens who work in their State of origin but reside in another Member State are also frontier workers under Article 45 TFEU. 
will allow them to truly integrate in another Member State. The use of the 'sufficient link of integration' test in these cases is nevertheless surprising, since Regulation 492/2011 does not allow for any additional requirements related to a worker's integration in another Member State, instead clearly stating that frontier worker status is in and of itself sufficient to enjoy full equal treatment. This type of test comes from the case law concerning the right of non-economically active citizens to benefit from social programmes: jobseekers, ${ }^{9}$ students, ${ }^{10}$ civilian war victims ${ }^{11}$ and disabled European citizens ${ }^{12}$ can be required to prove that they have a real or sufficient link to the society of the Member State in which they applied for benefits. These tests were introduced by Member States and accepted by the European Court of Justice as a form of compensation for the right to equal treatment granted, in principle, to all European citizens lawfully residing in other Member States regardless of their economic activity. As such rights were granted to new categories of European citizens, they were immediately curtailed by new 'entry tests' into the welfare State. ${ }^{13}$ However, this was initially always done under the premise that it was justified only insofar as it helped prevent 'social tourism', and did not apply to economically productive members of the employment market.

The extension of such tests to workers' access to social advantages such as student funding constitutes a worrying new encroachment of protectionist views on EU citizens' right to equal treatment. It will be argued that the requirement of 'sufficient links' for the children of frontier workers is not only contra legem (I), but also highly questionable regarding both its legitimacy and actual effectiveness (II), and is due to an evolution of the law concerning the rights of Union citizens that requires ambitious legislative reforms (III).

9 Court of Justice, judgment of 11 July 2002, case C-224/98, Marie-Nathalie D'Hoop v. Office national de l'emploi; judgment of 23 March 2004, case C-138/o2, Brian Francis Collinsv. Secretary of State for Work and Pensions; Court of Justice, judgment of 25 october 2012, case C-367/11, Déborah Prete v. Office national de l'emploi.

10 Court of Justice, judgment of 15 March 2005, case C-209/o3, The Queen, on the application of Dany Bidar v. London Borough of Ealing and Secretary of State for Education and Skills; judgment of 18 November 2008, case C-158/07, Förster v. Hoofddirectie van de Informatie Beheer Groep.

11 Court of Justice, judgment of 26 October 2006, case C-192/o5, K. Tas-Hagen and R. A. Tas v. Raadskamer WUBO van de Pensioen- en Uitkeringsraad.

12 Court of Justice, judgment of 1 October 20o9, case C-103/o8, Gottwald v. Bezirkshauptmannschaft Bregenz.

13 Iliopoulou, A. (2013). Le rattachement à l'État, cit., p. 654. 


\section{The Perplexing Extension of 'Sufficient Links' Tests to Frontier Workers' Social Advantages}

CJEU case law shows a very gradual, and perhaps not entirely intentional, progression towards fully accepting the use of 'sufficient links of integration' tests previously reserved for economically inactive citizens to frontier workers. The initial transfer was made in three questionable rulings in 2007 , but its explicit validation appears later, in case law concerning the rights of the children of frontier workers to apply for study finance in the Member State where their parent works. These developments appear to run contrary to secondary law, and to previous case law concerning the rights which workers derive from the Treaties.

\section{II.1 A Questionable but Minor Initial Development}

Before the rulings concerning student finance, there was one previous line of case law, that was noticed at the time, ${ }^{14}$ which seemed to extend 'sufficient links' tests to migrant workers. This line is in fact limited to three rulings made in 2007 concerning provisions excluding non-residents from the German child-raising allowance ${ }^{15}$ and the Wajong, a Dutch incapacity benefit for young people. ${ }^{16}$ Child-raising allowances typically constitute social advantages within Art. 7(2) of Regulation 1612/68, ${ }^{17}$ whereas the Wajong had been found to be a special non-contributory benefit within Art. 10a of Regulation 1408/71. ${ }^{18}$ Two of these cases dealt with "reverse frontier workers", nationals of the Member State where they worked who had simply changed their residence to another Member State. This could reasonably have been held to exclude them from migrant worker status, however, it did not seem to have a significant impact on the CJEU's assessment of the applicability of free movement rights as it held

14 See, in particular, the Comment on all three rulings by O'Brien, C. (2008). Comment on Case C-212/05, Gertraud Hartmann v. Freistaat Bayern, Judgment of the Grand Chamber of 18 July 2007, nyr; Case C-213/o5, Wendy Geven v. Land Nordrhein-Westfalen, Judgment of the Grand Chamber of 18 July 2007, nyr; Case C-287/05, D.P.W. Hendrix v. Raadvan Bestuur van het Uitvoeringsinstituut Werknemersverzekeringen, Judgment of the Grand Chamber of 11 September 2007, nyr. Common Market Law Review 45 (2), pp. 499-514.

15 Court of Justice, judgment of 18 July 2007, case C-212/05, Gertraud Hartmann v. Freistaat Bayern; judgment of 18 July 2007, case C-213/05, Wendy Geven v. Land Nordrhein-Westfalen.

16 Court of Justice, judgment of 11 September 2007, case C-287/05, D.P.W. Hendrix v. Raad van Bestuurvan het Uitvoeringsinstitut Werknemersverzekeringen.

17 Now Art. 7(2) of Regulation 492/2011.

18 'Special non-contributory cash benefits' are now covered by Art. 70 and Annex x of Regulation 883/2004 of the European Parliament and of the Council of 29 April 2004 on the coordination of social security systems. 
that both applicants could claim the status of migrant workers. ${ }^{19}$ Moreover, in all three cases, reliance upon Regulation 1612/68 and worker status for these frontier workers is combined with the acceptance of 'sufficient links' tests in an effort to mitigate the extension of the scope of such benefits to non-resident citizens. The result is a problematic series of precedents which would later be used as a foundation for an entirely different line of case law, concerning student finance.

The main issue at stake was whether Member States could restrict access to these advantages and benefits to residents, regardless of the claimants' nationalities. The German Government argued that the child-raising allowance was granted in order to benefit persons who, "by their choice of residence, [had ] established a real link with German society'. ${ }^{20}$ An exception was provided for frontier workers who had more than a "minor occupation" in Germany. This was not rejected by the Court, which held that the fact that this exception meant that frontier workers with more than minor occupations could, as it were, automatically pass the "real links" test. As the Court put it, the rule applicable to frontier workers meant that 'residence was not regarded as the only connecting link [...] a substantial contribution to the national labour market also constituted a valid factor of integration'.21 The result was that, while Mrs Hartmann must be granted the allowance because her spouse had a full-time job in Germany, Mrs Geven who was only in minor employment could be considered ineligible. ${ }^{22}$

Distinctions among migrant EU citizens based on the number of hours worked or the nature of the employment in a Member State were not new to the CJEU which had already admitted that migrant worker status depended on genuine and effective employment. ${ }^{23}$ The test applied here to determine whether someone was in minor employment nevertheless seems stricter than the traditional test defining workers under $45 \mathrm{TFEU}$. The main issue however is that non-resident EU citizens with "major" and "minor" occupations are both submitted to a test which does not apply to people who reside in Germany. There simply appears to be a presumption that frontier workers with major occupations meet the requirement of a real link with German society. This test was accepted in relation to a stated objective of increasing natality rates in Germany. The Court does not call into question the legitimacy of such an

\footnotetext{
19 Hartmann, cit., para. 18; Hendrix, cit., para. 46.

20 Hartmann, cit., para. 33.

$21 \quad$ Ibid., para. 36.

22 Geven, cit., para. 8.

23 Court of Justice, judgment of 23 March 1982, case 53/81, Levin v. Secrétaire d'Etat à la justice; judgment of 31 May 1989, case $344 / 87$, Bettray v. Staatsecretaris van Justitie.
} 
objective, nor its link with the number of hours worked in that Member State, which seems tenuous at best. ${ }^{24}$ Nor does the Court criticise the fact that this German law establishes a distinction between migrant workers and frontier workers. It seems to accept the idea that frontier workers who only have a minor occupation in Germany are not "sufficiently integrated" in German society.

The discrimination between frontier workers and residents constitutes a break with long-established case law which the Court does not even attempt to justify. The criterion chosen in this German legislation shows how awkward the attempt to apply 'real link' tests to workers can become. Here the CJEU requires the Member State to extend the territorial scope of a social advantage whose objective can only really be understood within the domestic territory. This is necessary for frontier workers because they benefit from equal treatment under Regulation 1612/68. However, proving that a frontier worker has a "sufficient link" with German society to the extent that they will contribute to increasing natality rates in that State is nigh impossible. The Court nevertheless has to accept a link between residence and the stated objective, as well as the unequal treatment between frontier workers and migrants. Yet this issue only arises because the Court accepts the 'sufficient link' test as a valid approach to determine whether frontier workers should benefit from social advantages in the Member State where they work. If one accepts that the childraising allowance at issue constitutes a social advantage within the meaning of Art. 7(2) of Regulation 1612/68, no difference should be established between migrant and frontier workers. Even if such a difference must be introduced, there is no justification for applying a type of 'sufficient link' test to frontier workers. Moreover, within the framework of the justification + proportionality test, the Member State has the upper hand in suggesting the type of test they deem appropriate. Here, the number of hours worked in Germany is the main criterion and could almost be understood as seeking to determine whether the person is in genuine and effective employment in the host State. However this was not the type of criterion relied upon in the later case law concerning student finance.

In the Hendrix Case, although Regulation 1408/71 enabled Member States to establish residence requirements for special non-contributory benefits, the Court held that since the Wajong also constituted a social advantage under Art. 7(2) of Regulation 1612/68 such a requirement, which does not ensure equal

24 Geven, cit., paras 21-23. In fact, the Court refuses to engage with the issues of the legitimacy of the objective and the link with a residence criterion, and instead chooses to focus on the fact that the residence criterion is not strictly applied so as to allow certain frontier workers to benefit from the child-raising allowance. 
treatment, must be proportionate to the legitimate objective pursued by the Dutch legislation..$^{25}$ According to the CJEU, national courts must interpret the national provisions in such a way as to take into account the worker's 'economic and social links' to the State in which they applied for the benefit. ${ }^{26}$ The situation was somewhat different in this last case, and called into question the overlap between Regulation 1408/71, which allows Member States to restrict access to certain benefits to residents, and Regulation 1612/68, which relies upon the principle of equal treatment for workers exercising their freedom of movement. At first glance, the priority given to the scope of Art. 7(2) of Regulation 1612/68, thus including frontier workers, appears to grant better protection to EU citizens who do not reside in the State in which they have applied for a specific benefit. ${ }^{27}$ However here too the problem lies in the way in which the Court frames the ratio decidendi, which grants significant leeway to the Member State in establishing a 'sufficient links' test restricting frontier workers' access to a social advantage.

The ease with which Member States got the CJEU to accept the legitimacy of their aims, the pertinence of 'sufficient link' tests and the criteria introduced to carry them out seems to indicate a lack of awareness on the Court's part of the importance of the break with previous case law concerning frontier workers. The Court certainly insisted upon applying equal treatment under the free movement of workers to borderline cases, and upon a proportionality test under which the citizen's personal circumstances must be examined. This could prima facie be considered a positive development for Union citizen's rights ${ }^{28}$ but the problem lies in the broader impact of allowing Member States to require frontier workers to prove their integration into the society in which they work. Despite these cases' peculiarities, the three rulings created precedents which the Court relied upon in later cases, a reference made easier by the insufficient care given to the processes by which precedents create norms in EU law. ${ }^{29}$ In these rulings, the Court enabled Member States to introduce differences between migrant workers and frontier workers, as well as among frontier workers, based on tests aiming to establish whether their links with the Member State are 'sufficient' to deserve access to social advantages. These rulings

25 Hendrix, cit., para. 54.

$26 \quad$ Ibid., para. 57.

27 Dougan, M. (2009). Expanding the Frontiers of Union Citizenship by Dismantling the Territorial Boundaries of the National Welfare States. In Barnard, C., Odudu, O., eds. The Outer Limits of European Union Law. Oxford: Hart, pp. 119-166, pp. 127-128.

28 Dougan, M. (2009). Expanding the Frontiers of Union Citizenship, cit., pp. 159-161.

29 On this issue, see infra, section III.1. 
seemed relatively innocuous until they reappeared in the case law relating to portable student finance.

\section{II.2 A Problematic Extension to Student Finance}

One unfortunate aspect of the right of students to free movement is that it does not create a uniform status for Union citizens travelling to other Member States to study. Rather, students benefit from very different rights, especially regarding access to certain forms of financial support from their host Member State or their State of origin, depending on whether they themselves or their parents are exercising their free movement rights as economically active Union citizens. Indeed, many forms of financial support for students are considered social advantages for their parents under Art. 7(2) of Regulation 492/2011. A student will therefore benefit from support from the Member State where at least one of his/her parents works, whether they are nationals of that State or not, as long as the worker continues to support the student. In this respect, as with other types of social advantages, frontier workers and migrant workers must in principle benefit from equal treatment under Art. 7(2).

A specific line of case law deals with the right of the children of frontier workers to benefit from a Member State's financial support for university studies abroad. Once again, we find Member States granting social advantages to residents first, thus restricting frontier workers' access to the same advantages. Here, the criterion based on major vs minor work in the host State has disappeared. The Member States, and the Court, seamlessly transition to "duration of work" criteria based on the "duration of residence" criteria applied to economically inactive citizens - another step in the pernicious influence of citizenship case law within the scope of the free movement of workers. The use of criteria based on the duration of the worker's employment in the host State makes it clear in these later cases that the Court is not inviting national authorities to determine whether there is a sufficient economic link, in the sense of genuine employment, justifying the application of Art. 7(2), but whether there is a sufficient link to the society as a whole, an integration within the national community.

The first ruling to apply the 'sufficient link' test to such cases is Commission v Netherlands. The Netherlands had made portable student funding conditional on the student having resided in the Netherlands for at least three of the six years preceding his/her enrolment for higher education abroad. ${ }^{30}$ This constituted indirect discrimination against frontier workers and migrant workers. 
This discrimination could not be justified by budgetary considerations in and of themselves, but the CJEU somewhat surprisingly stated that it had already recognised Member States' power to require nationals of other Member States to show a certain degree of integration in their societies in order to receive social advantages, even when they are economically active - while recalling that in principle, such a requirement for migrant and frontier workers is "inappropriate". ${ }^{11}$ In fact, Advocate General Sharpston examined whether evidence of a sufficient degree of integration could be required by a transfer of the Court's reasoning in the Förster and Bidar rulings, neither of which dealt with the free movement of workers. ${ }^{32}$ She refused to transfer the reasoning in these rulings to migrant workers insofar as it was invoked to avert an unreasonable financial burden, insisting that residence could not be the only acceptable evidence of connection with the Member State. ${ }^{33}$ She also warned of the dangers of allowing Member States to justify less favourable treatment of (both economically active and inactive) EU citizens in terms of social policy (integration) by applying access criteria such as length of residence. ${ }^{34}$

The Court did not follow its Advocate General and returned to the idea that the "link of integration" is to be presumed, but is an appropriate criterion, in cases involving migrant and frontier workers. The reasoning was similar to that followed in the three 2007 rulings: there is a discrimination, but it may be justified if the Member State uses criteria conducive to identifying the person's integration in its society and based on a legitimate overriding requirement. The CJEU proceeded to reject the Netherlands' justification based on the risk of an unreasonable financial burden, but accept the government's reasoning concerning the second justification, that of increasing student mobility. In a rather counterintuitive line of reasoning, the Court agreed that student mobility was indeed an overriding reason relating to the public interest ${ }^{35}$ and that a residence requirement was appropriate to meet that aim because it could ensure that the scheme was aimed first at students who would, in its absence, study in the Netherlands, and because Dutch authorities could legitimately expect students who benefit from the scheme to return to the Netherlands to enrich that Member State's job market. ${ }^{36}$ Advocate General Sharpston had, indeed,

$31 \quad$ Ibid., paras 63 and $65^{-66 .}$

32 Opinion of AG Sharpston delivered on 16 February 2012, case C-542/og, Commission v Netherlands, para. 74 .

33 Ibid., paras 87 and 122.

34 Ibid., para. 85 .

35 Commission v. Netherlands, cit., para. 72.

36 Ibid., paras $76-77$. The Court accepts the appropriateness of the residence requirement for the purposes of attaining the objective of promoting student mobility by simply 
stated that requiring a degree of integration from migrant workers was possible if justified by a legitimate social objective but did not support this with any reference to previous case law - in fact, the most explicit occurrence of this statement appears in a footnote. ${ }^{37}$

Despite the rejection of the actual criteria used in the Netherlands this ruling creates another precedent allowing Member States to apply 'sufficient link' tests to frontier workers. Indeed, the rejection of the actual criteria used by Member States in applying a 'real link' test does not constitute a rejection of the test itself, of its pertinence in a given situation, nor of the aims which the Member States rely upon. The force of the precedent lies in the ratio, thus the motives given by the Court for rejecting the specific rules at issue (or their later interpretation) are more important than the rejection itself. Once the Court accepts that Member States can look for "sufficient links" between frontier workers and their societies, the issue of legitimacy of such requirements transforms into a search for the appropriately worded overriding requirements and, more importantly, the specific threshold which the Court will deem proportionate.

A good illustration appears in Caves Krier Frères, ${ }^{38}$ concerning Luxembourgish subsidies for the recruitment of older unemployed persons. In this case, the CJEU seemed to firmly reject discrimination against a Luxembourgish frontier worker who had always worked in that State, but lived in another Member State. However the idea that a frontier worker's integration in the State where they work is not automatic but only to be presumed makes another appearance. The Court cites Commission v Netherlands as precedent in order to allow the use of integration tests but holds that, in the case at hand, 'Ms Schmidt-Krier is a frontier worker and a national of that Member State who has spent her entire working life there. Accordingly, she would appear to be integrated into the Luxembourg labour market'. ${ }^{39}$ Although this ruling appears to confirm that frontier

rephrasing the government's argument based notably on the fact that 'the Kingdom of the Netherlands expects that students who benefit from that scheme will return to the Netherlands after completing their studies, in order to reside and work there'. No further justification or any explanation is given as to the basis for this expectation, however both the Commission and Advocate General Sharpston seem to have found the aim of targeting students likely to enrich the Dutch employment market legitimate, see Opinion of AG Sharpston, Commission v. Netherlands, cit., paras 135-136.

Opinion of AG Sharpston, Commission v. Netherlands, cit., para. 91, footnote 54: 'This conclusion does not mean that I consider that in all circumstances Member States are precluded from requiring a degree of connection from migrant workers. Indeed, the social objective invoked by the Netherlands Government as justifying a degree of connection from all applicants is a legitimate aim which is justified by overriding reasons in the public interest'.

38 Court of Justice, judgment of 13 December 2012, case C-379/11, Caves Krier Frères Sàrl.

39 Ibid., para. 54. 
workers should be treated as migrant workers, it in fact consolidates the case law according to which such an equivalence is only based on a presumption that frontier workers have sufficient links with the State where they work. As later rulings show, this presumption is not absolute and perhaps only citizens whose links with the host Member State are as strong as Ms Schmidt-Krier's can safely assume they will fulfil the criteria. For instance, in its 2019 judgment in Aubriet, the Court recalls that 'the fact that migrant and frontier workers have participated in the labour market of a Member State creates, in principle, a sufficient link of integration with the society of that State', derived in particular from the worker's contribution to the financing of the social policies in question, but goes on to state that 'the Court has already accepted that indirectly discriminatory national legislation [...] where there is not a sufficient connection to the society [...] may be objectively justified'. ${ }^{0}$ Exactly why this contradictory status affecting the rights of frontier workers should exist is never explained. In this latest judgment, made without an Opinion, the Court's position seems to be that quoting the previous case law is entirely sufficient and no further explanation or justification is required.

The surprising combination of EU public interest objectives and purely national aims found in Commission $v$ Netherlands was seized upon by Luxembourg in the legislation at issue in the infamous Giersch case, now confirmed in two 2016 rulings, Depesme and Kerrou e.a. and Bragança Linares Verruga, and again in 2019 in Aubriet. A piece of Luxembourgish legislation introduced in 2010 put an end to the previous system of family allowances for children older than 18 and introduced financial support mechanisms based on scholarships and loans with a residence requirement for nationals of other Member States wishing to benefit from portable student funding. ALEBA, ${ }^{41}$ a trade union in the finance sector, supported hundreds of judicial actions by frontier workers who were thus excluded from this financial aid, which led to the four preliminary rulings. ${ }^{42}$ Luxembourgish legislation clearly created a discrimination against frontier workers, which the Court held to be incompatible with EU law - but in so doing, the Court reaffirmed that unequal treatment between

$40 \quad$ Nicolas Aubriet, paras 32, 33 and 34.

41 Association Luxembourgeoise des Employés de Banque et Assurance (Luxembourg Association of Banking and Insurance Employees). For an overview of the union's involvement in supporting families' efforts to challenge the legislative reform, see its Press release 'L'ALEBA fait le point dans le dossier CEDIES', 29 March 2018, available at: https:// www.aleba.lu/laleba-fait-le-point-dans-le-dossier-cedies/.

42 The union's lawyer, Maître Stéphanie Jacquet, was involved in the proceedings before the Court of Justice in Giersch, Depesme and Kerrou e.a. and Aubriet. 
resident and frontier workers was possible, provided the criteria were based on a legitimate aim and were proportionate. The reasoning followed in Commission $v$ Netherlands seemed coherent insofar as portable funding should reasonably not be used by students residing in other Member States for studies carried out in these States. However, the second stage of that reasoning was much more problematic as it implies that States are entitled to expect students to come back to the State which (partly) funded their studies in order to, as it were, justify the investment made. This seems to run absolutely contrary to the stated objective, since if students are expected to take full advantage of freedom of movement, they should be able to choose which part of the European Union they want to work in. The Luxembourgish justification set out in Giersch is slightly different. Instead of encouraging student mobility, the stated objective here is the promotion of the development of the national economy. ${ }^{43}$ Having all but abandoned any pretence that these rulings are based on European Union public interest objectives, ${ }^{44}$ the Court accepts a straightforwardly protectionist justification to the indirect discrimination caused by a residence requirement for financial aid for higher education studies in another Member State.

In both Commission v Netherlands and the Giersch line of cases, the Court finds that the national provisions are not proportionate to the objective pursued by the Member State if they set residence requirements which exclude frontier workers, or if they establish criteria which do not enable national authorities to take into account the specific circumstances of each case, e.g. by requiring an uninterrupted five year period of work in the Member State. ${ }^{45}$ However, it allows Member States to use the fear of social tourism to establish a potentially damaging distinction between migrant and frontier workers under Art. 45 TFEU.

\section{II.3 A Clear Break with Established Case Law and Secondary Law}

The case law concerning the access of frontier workers' children to portable study finance clearly appears to be contrary to the traditional understanding of frontier workers' rights. Despite the Court's - unsubstantiated - claim in

43 Giersch, cit., para. 48.

44 The Court and Advocate General Mengozzi do tie this objective to the promotion of tertiary education in the Europe 2020 strategy (Giersch, cit., paras 53-55; Opinion of AG Mengozzi delivered on 7 February 2013, para. $42 \mathrm{ss}$ ).

45 Bragança, cit., para. 69 - it must be noted that this Luxembourgish rule was an attempt to conform to the Court's earlier ruling in Giersch, whose para. 8o seemed to encourage such a criterion as an alternative to a residency requirement. 
Commission $v$ Netherlands, apart from the 2007 rulings which could otherwise have been considered an anomaly, there was no indication in previous case law that 'sufficient links' tests could be applied to frontier workers. Indeed, such tests should in principle be impossible if frontier workers are to benefit from migrant worker status under Regulation $492 / 2011 .^{46}$

As Advocate General Wathelet put it, 'there is, as it were, a presumption that the migrant or frontier worker is integrated into the Member State in which he works and to which he pays taxes and social contributions which contribute to the financing of the social policies of that State. ${ }^{47}$ But this presumption is not equivalent to automatic equal treatment deriving from migrant worker status under Article $45 \mathrm{TFEU}$. The Court stated in Commission v Netherlands that the link between migrant workers and frontier workers arises from their contribution to the financing of the State's social policies through taxes. ${ }^{48}$ This was the position which justified equal treatment in access to social advantages for all workers exercising their free movement rights, regardless of the duration of their residence or employment in the Member State.

Requiring proof of integration for frontier workers thus amounts to ignoring their contribution to the costs of the social policies they want to benefit from. By considering such criteria as a valid step in the proportionality test of a justification, the Court has therefore introduced a new requirement that is clearly incompatible with Article 7(2) of Regulation 492/2011. In doing so, despite its insistence on the presumption of integration and on a case-by-case examination of individual situations, the Court has created the risk of further differentiation between migrant workers and frontier workers. The difficulties in articulating the territorial and personal scopes of Regulations 492/2011 and 1408/71 emphasize the issues posed by the status of frontier workers. They cannot fully be considered members of the national community of the host Member State in the sense associated with traditional understandings of solidarity within the national community, and do not fulfil the residence criteria often used to extend that solidarity within Union citizenship on the basis of 'real link' tests. However, by including them in the scope of the free movement of workers, EU law requires Member States to find different mechanisms to allow them to benefit from social welfare. The use of "duration of work" criteria

46 Contra, Hoogenboom, A. (2012), Export of Study Grants and the Lawfulness of Durational Residency Requirements: Comments on Case C-542/o9, Commission v the Netherlands. European Journal of Migration Law 14 (4), pp. 417-438, 427.

47 Opinion of AG Wathelet delivered on 2 June 2016, case C-238/15, Bragança Linares Verruga e.a., para. 69 . 
for frontier workers seems to be an ill-conceived attempt to solve this issue by resorting to 'sufficient link' tests that are applied without sufficient care or rigour. ${ }^{49}$ Another risk in applying contra legem criteria linked to the duration of work to determine whether frontier workers can access social advantages is that it is difficult to see why such requirements should only apply to frontier workers and not to resident migrants. In any case, the Court's reasoning is insufficient to establish a clear motive for different implementations of Regulation 492/2011 based on the worker's place of residence. This line of case law is based on a highly problematic approach whose viability in practice has not been proven.

\section{I A Contentious 'Investor's Approach' to Social Advantages}

The case law derived from Commission $v$ Netherlands is not only questionable because of its practical implications for the rights of frontier workers and their children. Its social and political consequences are unfortunate but they remain rather limited to this day. More worrying are the facts that this case law does not rely on a convincing line of argument and that the leeway it grants Member States could have unpredictable consequences considering the often insufficiently reasoned use of precedent in CJEU case law. ${ }^{50}$ Both the legitimacy of the objectives presented as overriding reasons of public interest and the logical connection between them and the tests used to establish 'sufficient links' are highly contentious.

\section{III.1 Questionable Legitimacy}

The reasoning followed by the Court in cases Commission $v$ Netherlands and Giersch seems to be that the difference between cases concerning migrant workers and those concerning economically inactive citizens is not that migrant workers do not need to prove their degree of integration, but that such a requirement cannot be based on purely budgetary preoccupations such as an unreasonable burden on financial assistance programmes and must instead be linked to a social objective. ${ }^{51}$ Even if one accepts the introduction of such

49 We are certainly very far from the 'rigorous comparability model' advocated for in Dougan, M., Spaventa, E. (2005). 'Wish You Weren't Here'... New Models of Social Solidarity in the European Union. In Dougan, M., Spaventa, E. (eds). Social Welfare and EU Law. Oxford: Hart, pp. 181-218.

50 See infra, section III.1.

$5^{1}$ See paras. 49-52 of the Opinion of AG Mengozzi, Giersch, cit. 
a criterion to restrict frontier workers' access to certain social advantages, the validity of the governments' reasonings is highly doubtful.

First, the objectives put forward by both governments are clearly linked to protectionist concerns that are almost indistinguishable from the financial objectives which the Court purports to reject. This was already clear in Commission $v$ Netherlands since, although the objective recognised by the Court of Justice was to increase student mobility, which is indeed a matter of public interest for the European Union as a whole, the Court also seemed to accept the idea that Member States could legitimately expect students who benefit from financial support to return to the country that funded their studies. ${ }^{52}$ Funding student mobility thus becomes an investment in the State's own economy ${ }^{53}$ and not a contribution to the general European Union objective of promoting the free movement of persons. The ruling does not appear to take into account the flagrant contradiction between these objectives, only one of which could reasonably be linked to an overriding requirement. To the contrary, the Court almost seems to be encouraging Member States to establish rules which allow them to restrict funding to students who are likely to later enter their job markets.

The leniency towards Member States appears even more clearly in the $\mathrm{Gi}^{-}$ ersch line of cases, in which the Court accepts as an overriding requirement not the promotion of student mobility, but an increase in the percentage of Luxembourg residents with a higher education degree. A justification of the way in which this national objective is supposed to contribute to European public interest is nowhere to be found, beyond the very loose connection drawn by Advocate General Mengozzi and the Court with the Europe 2020 strategy promoting a knowledge economy. ${ }^{54}$ However, the strategy promotes higher education as an aim for the European Union job market as a whole, not for each Member State individually. Why this European strategy can be more effectively pursued by promoting the return of students having obtained such degrees to Luxembourg rather than allowing them to choose the Member State where they wish to work is never explained. Similarly, the Court never explains why Luxembourg should legitimately expect to meet aims related to the composition of its labour market by promoting the return of students whose parents

52 See supra, section I.2.

53 Skovgaard-Petersen, H. (2013). There and Back Again: Portability of Student Loans, Grants and Fee Support in a Free Movement Perspective. European Law Review 38 (6), pp. $783-8$ o4, 798 .

Opinion of AG Mengozzi, Giersch, cit., paras 42-45, judgment, cit., paras 53-55. 
already have links with its economy rather than by attracting other graduates. ${ }^{55}$ Indeed, it seems unlikely that such an explanation can be found. And yet, the Court of Justice keeps insisting that the link exists or rather blindly quoting its own previous rulings as sufficient proof that it does. In Aubriet, the Court thus states that it has already "accepted" that a length of employment requirement in the State granting the aid on the part of the frontier worker parent 'is such as to establish such a connection on the part of those workers to the society of that Member State and a reasonable probability that the student will return to that granting Member State after completing his studies. ${ }^{56}$ Hence, a connection that entered the case law without any logical justification is now being quoted as valid simply because it has entered the case law.

Commission $v$ Netherlands thus seems to have opened Pandora's box in allowing Member States to present the funding of portable student finance as an investment on which they can legitimately expect a return. This is not only problematic in that it serves as the basis for the application of 'sufficient links' tests implementing a justification to an indirect discrimination, it goes against the Court's usual position on overriding requirements. In principle, there must be a clear European public interest aim to justify obstacles to free movement, and protectionist or purely national aims are not acceptable this is the basis for the exclusion of budgetary concerns as an overriding requirement except in certain specific areas of CJEU case law. The admission of the "investor's approach" to student funding raises serious questions. Firstly, the aim of ensuring the return of students who have benefited from financial support seems to run contrary to the aims of Union citizenship and free movement rights, if one accepts that citizens should be encouraged to think of the whole of the single market as a space in which they can freely choose where to study or work. Secondly, it omits the other costs related to higher education, for instance those incurred by the Member State where the worker's child wishes to study. Even in States where higher education is not free, universities depend to a very large extent on government spending and the costs of hosting students from another Member State was the basis for previous rulings relating to student mobility within the EU. Thirdly, it is difficult to determine how far beyond portable student finance this type of reasoning could become acceptable. Since these cases partly rely on precedents concerning child-raising allowances and incapacity benefits, it is conceivable

55 Turmo, A. (2016). Accès des frontaliers aux aides aux études luxembourgeoises - Des précisions insatisfaisantes sur l'arrêt Giersch. Revue des affaires européennes, n. 4, pp. 701-712, 706 .

Nicolas Aubriet, para. 36, quoting Bragança, para. 58 . 
that Member States will try to use similar criteria to restrict frontier workers' access to all types of social advantages.

\section{III.2 Questionable Workability}

The aims which the Netherlands and Luxembourg relied upon to justify residence or duration of work requirements do not merely appear to be of questionable legitimacy in and of themselves. The connection established between them and the 'sufficient link'-based proportionality tests, and the appropriateness of the criteria chosen by the Member States in order to establish whether such a link exists, are both highly doubtful. Even if one were to accept that the investor's approach to student finance can form the basis for overriding reasons of public interest, it seems unlikely that Member States can in fact implement this approach while complying with freedom of movement, by establishing objective criteria which Union citizens may rely on.

The two Member States' reasoning appears to be based on the postulate that a student whose parent has a 'sufficient link' with the Member State in which she applies for student funding is extremely likely to join that State's labour force after she has obtained her degree, thus benefiting the national economy. However, not only does this expectation seem contrary to the aims of freedom of movement within the internal market which should prevent Member States from trying to force graduates to enter their own employment markets, ${ }^{57}$ but as Advocate General Sharpston wrote in Commission $v$ Netherlands, 'it is not selfevident that past residence is a good way of predicting where students will reside and work in the future. ${ }^{58}$ Indeed, it seems just as likely that the student will seek their first job in the very Member State where they have obtained their degree.

This is made all the more obvious by the fact that, since these cases deal with student finance understood as a social advantage granted to the student's parent, the test seeking to establish integration in the State's society applies not to the student but to their parent. ${ }^{59}$ Significantly, the Court itself had rejected the opposite argument that a person residing close to the border with

57 Van der Mei, A. (2005). EU Law and Education: Promotion of Student Mobility versus Protection of Education Systems. In Dougan, M., Spaventa, E. eds, Social Welfare and EU Law, cit., pp. 219-240, p. 228.

58 Opinion of AG Sharpston, cit., para. 147, see also para. 43. The Advocate General was 'not convinced that there is an obvious link between where students reside prior to pursuing further education and the likelihood that they will return to that Member State after completing their studies abroad'.

59 Ibid., para. 43: 'the Kingdom of the Netherlands cannot legitimately assert that the place where the migrant worker or his dependent children will study will be determined, in a quasiautomatic manner, by the place of residence'. 
the State where they completed their studies is more likely to enter that State's labour market, because the knowledge acquired by a student in the course of his higher education does not in general assign him to a particular geographical employment market. ${ }^{60}$ If the place where a person studies cannot be considered a systematic indication of the labour market they will join, the same must be true for the place(s) where their parents live, or where they have worked in recent years as frontier workers. Moreover, even if it were possible to prove that a student whose parents work in a Member State is more likely to seek employment there after obtaining a degree, the very nature of the single market means that there is no way to predict whether they will remain there for a long period of time. The "return on investment" can only be presumed in the short term, if at all. Inversely, the claimant in Aubriet, who did not receive any financial aid from Luxembourg for his studies in France and continues to reside in that country like his father, carried out his professional training with a Luxembourgish employer which went on to recruit him. ${ }^{61}$

Systems which make the grant (or the non-reimbursement) of portable funding conditional upon the student's 'return' to join a State's labour market would establish a much clearer logical foundation for the investor's approach. Member States in fact seem to be encouraged to resort to such solutions. While Advocate General Sharpston noted that she was not convinced that past residence was a good way of predicting where students would reside and work in the future, she referred in a footnote to 'ways of encouraging that to happen' such as making the grant of funding 'conditional upon the student returning to the Netherlands to work there for a minimum period of time'.62 Although such rules again appear to clash with the aims of freedom of movement, they at least have the advantage of relying on a demonstrable logical connection between the criterion used and the expected short-term results.

Nowhere in this case law do we find any proof that the Member States gave concrete and precise evidence of the link between the parents' previous residence or work in a State and their children's integration in that State's labour market after pursuing higher education abroad. This is mostly apparent in the Court's examination of the proportionality of the specific requirements that are supposed to establish the 'sufficient link'. The Court's Commission v Netherlands and Giersch rulings clearly exclude residence requirements which discriminate against frontier workers, but do not exclude the use of criteria based on the duration of the link with a Member State in order to prove integration.

6o Court of Justice, judgment of 25 October 2012, case C-367/11, Prete, para. 45.

61 Nicolas Aubriet, para. 17.

62 Opinion of AG Sharpston, Commission v. Netherlands, cit., footnote 74 (under para. 147). 
The question then becomes how many years constitute "sufficient" integration, and whether non-continuous periods of residence and/or work can be taken into account. The fact that in the specific cases at issue the Court found criteria that excluded frontier workers incompatible with the Treaty does not suffice since the later case law shows that certain criteria, which are discriminatory towards frontier workers, can be acceptable.

In Bragança, the Court held that the requirement of an uninterrupted five years period of work in the Member State was discriminatory because it did not apply to residents, and disproportionate to the objective already set out in Giersch. According to the Court, the five year residence criterion did not permit the competent authorities to grant that aid where, as in the main proceedings, the parents, notwithstanding a few short breaks, have worked in Luxembourg for a significant period of time, in this case for almost eight years, in the period preceding that application, involves a restriction that goes beyond what is necessary in order to attain the legitimate objective of increasing the number of residents holding a higher education degree, inasmuch as such breaks are not liable to sever the connection between the applicant for financial aid and the Grand Duchy of Luxembourg.63

Current Luxembourgish law, introduced before the Bragança and Depesme and Kerrou rulings, requires the non-resident student's parent to have worked in the Member State for five out of the seven years preceding the application for financial support. ${ }^{64}$ Previous case law seemed to indicate that such a rule could be compatible with EU law since, as the Luxembourgish Government argued, it made it possible to take into account cases of quasi-continuous employment in that Member State over the previous years. Although the Government was confident that this was a good way to take into account the Court's case law, the ruling in Aubriet forcefully contradicts this view. In a relatively short judgment, without an Opinion and where most of the argument is based on repeating the last three rulings concerning Luxembourg, the Court found that the five out of seven year rule did not meet the requirements of the "necessity" stage of the proportionality test.

One must admit that the five-out-of-seven-years rule seems a very high threshold considering the children of migrant workers are in principle able to benefit from the grant regardless of the duration of their parent's work in Luxembourg. Moreover, the Bragança ruling contains no evidence that the Luxembourgish government had showed how such a criterion would be better

\footnotetext{
63 Bragança, cit., para. 69 .

64 Loi du 24 juillet 2014 concernant l'aide financière de l'État pour études supérieures (Mémorial A 2014, p. 2188).
} 
suited than another to ensure that the students join its labour market after obtaining their degrees abroad. The Court's lax approach to the proof of the appropriateness of national measures discriminating against frontier workers in these rulings clashes with the general trend in the case law. ${ }^{65}$ Indeed, the situation of Mr Aubriet's father, who, as the Court remarks, had been working in Luxembourg for more than 17 years out of the previous 23 when his son submitted his application, demonstrates the negative effects of a rigid criterion such as the one set out in 2014 and, more broadly, of allowing Member States to establish such limitations to the rights of frontier workers.

The only explanation for the explicit admission of a protectionist goal as an overriding requirement (after less explicit admission in Commission $v$ Netherlands) and the lack of proper examination of the appropriateness of the national provisions must be the specific sociological and economic circumstances visible in Luxembourg today. These factors are only mentioned in passing in Advocate General Mengozzi's Opinion in Giersch $^{66}$ but they must have played a significant role in the Court's understanding of the Luxembourgish justification for such restrictions to frontier workers' rights. In 2016, Luxembourg's population included 46,71\% foreign residents and, in the second trimester of 2017 , $45 \%$ frontier workers among its employees. ${ }^{67}$ Previous case law has shown that this State's small size and large proportion of migrant and frontier workers leads to specific issues regarding the application of freedom of movement under EU Law. ${ }^{68}$ Fears that the stability of a portable student finance programme could be threatened by full access for the children of frontier workers indeed seem more reasonable in the Luxembourgish context than in most Member States. However, precisely because the Court does not consider budgetary concerns acceptable overriding reasons in the public interest, no reference is ever made to the true motives of Luxembourg's restrictive criteria.

If the Luxembourgish context was a deciding factor in these three rulings, this was not made explicit by the Court. The lack of any indication within the

65 O'Leary, S. (2014). The Curious Case of Frontier Workers and Study Finance: Giersch. Case C-20/12, Elodie Giersch v. État du Grand-Duché de Luxembourg, Judgment of the Court of Justice (Fifth chamber) of 20 June 2013, nyr. Common Market Law Review $5_{1}$ (2), pp. 6o1-622, 612, quoting Nic Shuibhne, N., Maci, M. (2013). Proving Public Interest: The Growing Impact of Evidence in Free Movement Cases. Common Market Law Review 50 (4), pp. 965-1005.

66 Opinion of AG Mengozzi, Giersch, cit., para. 46: the Advocate General only refers to Luxembourg's atypical economic history and current situation.

67 According to data collected by Statec, Luxembourg's National Institute of Statistics (www. statistiques.public.lu). 
rulings themselves that the admissibility of the overriding reason in the public interest, or any other aspect of the Court's reasoning, is only applicable in the very specific circumstances found in Luxembourg, leaves the rulings open for wider interpretation and creates dangerous precedents. The more or less implicit admission of similar national goals in Commission v Netherlands and the lack of circumscription of the Luxembourg rulings to a specific local context could lead to a multiplication of similar provisions restricting access to social advantages such as student finance for frontier workers. Once again the lack of sufficient care in construing and creating precedents is at the root of the problem. A clear indication of the scope the Court wanted to give these rulings would have significantly reduced the potential impact of this ruling and the gravity of the contra legem rule being created.

Perhaps even more alarmingly, the case law as constructed by the Court of Justice is impossible to apply in practice. Aubriet is a perfect illustration of the impractical nature of the Court of Justice's precedents on this issue. Luxembourg reminded the Court that applications for student financial aid are processed through a "standardised mass procedure". ${ }^{69}$ This means that objective and neutral criteria are required because the competent authorities cannot be expected to carry out a literal case-by-case analysis of each application. Requiring an authority, that has to process hundreds of applications within a relatively short time period every year, to carry out a full assessment of the particular circumstances of each case and to look for a "sufficient connection with Luxembourg society", a subjective element, is simply unrealistic. Moreover, as they could have added, such a procedure could, in the absence of objective criteria, significantly affect the rights of EU citizens as it would cause too much uncertainty.

What Aubriet proves, therefore, is not only the ill-suited nature of the criterion chosen by Luxembourg ( 5 out of the previous 7 years) but the serious danger which results from allowing such 'sufficient links' tests to be carried out on frontier workers in the first place. Luxembourg is perfectly justified in insisting that a true case-by-case analysis is ill-suited to the type of application process at issue. National authorities and applicants need clear, objective criteria. The Aubriet ruling produces is an insoluble problem: it seems that no objective criterion based on a reasonable duration of employment in the Member State can meet the Court's requirements for a case-by-case analysis, however any other type of assessment leads to excessive uncertainties and workloads at the national level. The Court states that the current criterion 'is not sufficient to make

69 Aubriet, paras 41-43. 
full assessment of the significance of that cross-border worker's connections with the Luxembourg labour market, ${ }^{70}$ but what would? The Court gives no clues as to what the preferable options would be.

How far in the past should competent national authorities go in assessing the applicant's parents' ties to the national labour market? Five out of the last seven years seemed just as pertinent a criterion as seven out of the last ten, or four out of the last six. A wider time frame also implies a greater burden placed on applicants to prove their parents' ties over a longer time period. Is it truly better to require students wishing to apply for financial support for studies in a neighbouring State to provide evidence that one of their parents was already working in Luxembourg fifteen years ago? Perhaps in this case it seems too harsh to reject an application made by a student whose father had worked in Luxembourg for the greater part of 23 years, but it seems just as harsh to force every nonresident applicant to submit evidence covering a twenty-year period, bearing in mind this is already a contra legem exception to the rights of frontier workers.

The real issue is that, while Member States have been allowed to introduce duration of residence criteria to prove 'substantive links' in the field of citizenship, such criteria, once set, are bound to exclude a number of citizens in a somewhat arbitrary fashion even when, as was the case here, they allow for some flexibility. This exclusionary effect seems even more difficult to justify when applied to citizens who should in principle benefit from the rights at issue not by virtue of the duration or solidity of their "links" with a society but simply because they are frontier workers. This is an easily foreseeable consequence of allowing Member States to introduce such criteria to begin with, as true case-by-case analysis of the subjective links between an individual and the society of the Member State is out of the question in the assessment of student applications for financial aid (and, realistically, in most other cases). In Aubriet the Court seems to renounce its own case law's actual capacity for implementation as the easiest option to comply with it seems to be to abandon duration of work criteria for frontier workers altogether. The case law remains, however, and its potential full impact is difficult to predict.

\section{A Problematic Case Law Caused by the Absence of Ambitious Legislative Reforms}

The five rulings concerning student finance could have major consequences for portable student finance in the European Union, encouraging Member 
States to introduce provisions that could make such funding conditional upon the student's return and integration into their own labour markets after having completed their studies. However, more importantly, this case law could have wide-ranging consequences for frontier workers and the status of migrant workers as a whole. The access to social advantages under Regulation 492/2011 is being restricted on the basis of criteria such as the duration of one's residence or work in the host Member State, which were developed in the secondary law and case law applicable to economically inactive Union citizens. This appears to be an involuntary result of Member States' adaptation to the Court's case law. As new rights become available for economically inactive Union citizens, and as the duration of one's stay in a Member State becomes a determining factor to establish one's status under instruments such as Directive 2004/ 38 , worker status is losing the power it once had. As Member States prioritise the rights derived from Union citizen resident status, legislative reform is necessary to establish a new balance between these rights and those derived from migrant worker status.

\section{IV.1 The Uncertain Development of a Specific Status for Frontier Workers} The first consequence of this case law, beyond the specific case of student finance, is an explicit admission by the Court of Justice that unequal treatment between frontier and migrant workers may be justified in relation to social advantages. Indeed, the Court has not yet held that 'sufficient links' tests are applicable to migrant workers who reside in the Member State where they work.

This difference cannot be based on Regulation 492/2011 nor on traditional case law on the free movement of workers, but seems to have been introduced by the Court in 2007 Cases Hartmann and Geven, which are referred to in $\mathrm{Gi}^{-}$ ersch, and in Commission v Netherlands which itself does not refer to any sources on this issue but can only be understood if one takes into account those rulings. ${ }^{71}$ In these three rulings, the Court certainly tried to resist Member States' attempts to exclude frontier workers from access to social advantages. However, in doing so by introducing a proportionality test linked to a justification, it enabled States to reason in terms of 'sufficient links' to their labour markets. The Court thus introduced a fundamental shift in the understanding of the status of frontier workers in EU law and of the basis for their access to equal treatment regarding social advantages.

71 Advocate General Sharpston did refer to Geven, but only in support of the statement that Art. 7(2) of Regulation 1612/68 expresses the principle of equal treatment set out in Article $45 \mathrm{TFEU}$. The Court referred to the same ruling in support of the equality of migrant and frontier workers as regards Art. $7(2)$. 
The Court in fact accepts this inequality between migrant and frontier workers as a valid option for Member States. For instance, there is nothing in the case law to suggest that the new Luxembourgish rules on student finance, introduced before the 2016 rulings, are incompatible with either the treaties or secondary law, despite the fact that they explicitly grant different rights to the children of migrant workers (or of Union citizens having acquired permanent residence) and to the children of frontier workers, with only the latter being submitted to a test establishing the duration of employment. ${ }^{72}$ The Court states that such a difference can lead to indirect discrimination, ${ }^{73}$ but may be justified by an objective in the public interest if the distinction is based on criteria aiming to establish the student's parents' integration in Luxembourgish society. The fact that frontier workers contribute to paying for these social advantages through taxes in the same way as migrant workers no longer seems to shield them from requirements that do not apply to residents. To what extent such distinctions can affect the integrity of frontier worker rights under Art. 45 TFEU is as yet unclear. But there is no reason to suppose that they will remain restricted to the specific cases dealt with in the 2007 rulings and to student finance.

The uncertainty associated with the risk of extending such exceptions beyond the limited scope of the current case law is due to the CJEU's insufficient rigour in developing and applying precedent. There can be no doubt that the Court does rely on precedent, but this line of case law is a good illustration of the deficiencies of the current absence of any clear doctrine of precedent in European Union law. ${ }^{74}$ For instance, note the ease with which the 2007 cases are quoted as precedent in para. 64 of Giersch as a sufficient basis for the statement according to which 'with regard inter alia to frontier workers, the Court has allowed certain grounds of justification concerning legislation which distinguishes between residents and non-residents carrying out a professional activity in the State concerned, depending on the extent of their integration in the society of that Member State or their attachment to that State. ${ }^{75}$ The facts that two of these cases concerned 'reverse' frontier workers, that they did not deal with

72 Art. 3 (2) and (5) of the 24 July 2014 Loi concernant l'aide financière de l'État pour études supérieures, Mémorial A n ${ }^{\circ} 139$.

73 Bragança Linares Verruga, cit., para. 47.

74 On the use of precedent by the Court of Justice, see the brilliant analyses by Komárek, J. (2007). Precedent in European Union Law: Reasoning with Previous Decisions of the Court of Justice. Thesis (D.Phil.). University of Oxford; and Jacob, M. (2014). Precedents and Case-Based Reasoning in the European Court of Justice: Unfinished Business. Cambridge: Cambridge University Press.

Giersch, cit., para. 64 . 
student grants, or that the German legislation at issue in two of them based the criterion applicable to frontier workers on the intensity of the economic activity pursued in the host state are not mentioned. No attempt is made to justify the analogy and a general rule is derived from three peculiar rulings made 6 years earlier, which seem to allow Member States to impose 'real link' tests which discriminate against non-resident workers. In Giersch, this seems to be introduced as a wide-ranging exception to the presumption, restated in Caves Krier Frères, that frontier workers have established sufficient integration through participation in the employment market. ${ }^{76}$

Similarly, although the Luxembourgish cases clearly seem linked to the specific circumstances in that Member State, the rulings do not make any reference to a specific economic or social context justifying an exception but appear to state a general rule. This means that they could potentially be quoted as precedent by any Member State seeking to restrict frontier workers' access to social advantages. Such transfers from one line of case law (or one area of the law) to another are frequent in CJEU case law, and do not meet the standards of rigour and justification that should be expected in a complex precedentbased system. Citations of Giersch appear to have taken on a life of their own, with Advocates General and the Court now referring to it as a precedent for the rule that the free movement of workers prohibits all forms of discrimination, including cases where the national measure does not place all nationals of other Member States at a disadvantage, or also affects some nationals of the State in question. ${ }^{77}$ These citations have little to do with the actual precedential value of Giersch in the Court's overall case law on freedom of movement. However, they could produce serious consequences by normalising references to a very specific and controversial line of cases. Greater care in formulating new case law and, most importantly, in engaging explicitly with precedent would probably have allowed the Court to restrict the impact of the 2007 rulings, as well as that of Commission v Netherlands and Giersch. Aubriet provides excellent evidence of this, as the Court appears to assume that previous case law is entirely sufficient to answer the preliminary reference, while giving the national judges a new ruling which contradicts previous assumptions as to the type of national rule that would be compatible with EU law, and leaves little room to find a workable alternative.

76 This is quoted in Giersch, cit., para. 63 .

77 Court of Justice, judgment of 13 March 2019, case C-437/17, Gemeinsamer Betriebsrat EurothermenResort Bad Schallerbach, para. 31 (see also the Opinion of AG Saugmandsgaard Øe, delivered on 25 July 2018, paras 8 and 34); Opinion of AG Bobek delivered on 23 May 2019, case C-703/17, Krah v. Universität Wien, para. 54 . 


\section{IV.2 A Consequence of Member States' Adaptation to Union Citizen Rights}

One interesting aspect of all these rulings is that the Member States were clearly trying to comply with Directive 2004/38. They agreed to grant full equal treatment to migrant workers and to citizens who had acquired permanent residence, as is the case in the legislation passed in Luxembourg following $G i$ ersch. A test related to the "major" or "minor" nature of the work carried out in the host Member State only appears in the 2007 cases and we see a clear shift towards criteria based on the duration of one's integration in the host state. Even in Commission v Netherlands, where national authorities wanted to apply a criterion related to the duration of residence to all migrant workers, such a solution was clearly inspired by previous case law concerning the 'sufficient links' tests applicable to economically inactive citizens and by Article 24(2) of Directive 2004/38. ${ }^{78}$

The link between frontier workers' rights and the rights derived from permanent residence under the Directive was brought up by the Court of Justice itself in Giersch, when it suggested that Member States could make financial support conditional on the parent of the student having worked in Luxembourg for a minimum period of time. The Court seemed to add an indication as to what that period could be by referring to the five years' residence condition set in Art. 16(1) of Directive 2004/38, ${ }^{79}$ although it then denied this analogy's relevance and rejected such a strict criterion in Bragança. ${ }^{80}$ Despite this apparent contradiction in the case law, the relevance of analogies between the status of frontier workers and that of all citizens under Directive 2004/38 is made clear by the introduction of a test developed within the case law concerning economically inactive citizens into the interpretation of Article 45 TFEU and of Regulation 492/2011.

These rulings clearly show an influence of the case law and legislation concerning economically inactive citizens over the status of certain workers exercising their free movement rights. Although migrant workers' rights appear to be guaranteed, frontier workers find themselves excluded from the full benefit of equal treatment simply because they do not reside in the Member State. This criterion is contrary to the traditional approach which links rights granted

78 'By way of derogation from paragraph 1 , the host Member State shall not be obliged [...] prior to acquisition of the right of permanent residence, to grant maintenance aid for studies, including vocational training, consisting in student grants or student loans to persons other than workers, self-employed persons, persons who retain such status and members of their families.'

79 Giersch, cit., para. 8o.

8o Bragança Linares Verruga, cit., para. 65-70. 
under Article 45 TFEU not to residence, but exclusively to worker status. The 'sufficient links' test, which is typically based on the duration of residence, finds itself being implemented through duration of work criteria which bear no relation to the principle that the very status of migrant or frontier worker is sufficient, in and of itself, to justify equal treatment.

The transfer of tests constructed in the context of economically inactive citizens' rights to frontier workers also leads to a clear restriction of the rights associated with migrant worker status, a reversal which gives priority to the rights derived from long-term residence in a Member State. Although migrant workers are not necessarily impacted by this case law in the short-term, there seems to be a shift from the higher protection granted to workers to a distinction between migrant workers and other citizens residing in a Member State, and those workers who do not permanently reside there. This is a fundamental shift in the traditional hierarchy among categories of citizens exercising free movement rights, and it could eventually lead to significant restrictions of frontier workers' rights, as well as those of all citizens exercising their Article $45 \mathrm{TFEU}$ rights if duration of work or residence criteria became the general rule for economically active citizens too. This would not be a major issue if it was part of a more general and well-reasoned shift towards granting priority to Union citizenship rights and applying tests derived from the idea of a 'real link' with sufficient rigour and legal certainty. ${ }^{81}$ However, the case law provides no clear indication that this is the case and, instead, gives the impression that the CJEU is almost unwittingly expanding the scope of an exception that was highly questionable in the first place.

\section{IV.3 The Need for Legislative Reform}

One of the root causes for this case law is clearly the attempt by many Member States to introduce restrictions on Union citizens' access to social benefits while conforming to Directive 2004/38, and the European Court of Justice's attempt to assuage fears of "social tourism" or, more specifically, "study grant forum shopping". ${ }^{22}$ By trying to take into account what it felt were legitimate concerns about granting access to social benefits to people who were not truly migrant workers, in the sense that they were "reverse" frontier workers or that they only had a minor professional occupation in the host Member State, the Court of Justice made three very awkward rulings which have served as a precedent for a potentially far-reaching limitation of all frontier workers' rights. As

\footnotetext{
81 See Dougan, M., Spaventa, E., 'Wish You Weren't Here', cit., pp. 217-218.

82 In the words of the Court in Giersch, cit., para. 80, and Bragança Linares Verruga, cit., para. 57 .
} 
in other aspects of free movement law, it has transformed an issue related to the applicability of free movement rights and the appropriateness of national measures to their stated objectives into one of proportionality, ${ }^{83}$ using a test which the Court itself considers inapplicable, in principle, to the free movement of workers. This will lead Member States to construct ever more complex legislation establishing criteria designed to prove the (lack of) integration into their societies of Union citizens who are already working there. Unfortunately, the Court's efforts to maintain frontier workers' rights do not fully compensate for the impact of allowing such a distinction with migrant workers to develop in the first place. ${ }^{84}$

In relation to student finance, one cannot help noticing that this is the result of the absence of an EU-wide mechanism to determine which State should be responsible for funding access to higher education for mobile EU citizens. The case law already shows the absurd complexity of a system designed to fund student mobility which depends on one the student's parents being sufficiently "integrated" in a State's economy. Depesme \& Kerrou shows that proof of what constitutes a parent-child relationship for the purposes of determining access to social advantages is not always easy. The frontier worker may be a step parent but they must actually contribute to the maintenance of the student, whereas student finance is in principle designed specifically so that students whose parents cannot support them have access to higher education. ${ }^{85}$

The specific examples which appear in the Depesme \& Kerrou cases show how problematic the existence of separate categories of mobile students under EU law can become. At the very least, it seems excessively convoluted to have the right to access higher education in another Member State or to benefit from financial support for such studies depend on whether one or one's parents are migrant workers, frontier workers, inactive citizens with permanent residence in another Member State, or "static" Union citizens. Moreover, the Court almost seems to be encouraging Member States to set up systems which restrict access to full financial support to students who return to join their labour markets.

Such schemes indeed answer Member States' concerns but they are contrary to the aims of free movement. These issues clearly derive from the lack

83 Nic Shuibhne, N., Maci, M., Proving Public Interest, cit., p. 1005.

84 Regarding the 2007 cases, see contra Dougan, M., Expanding the Frontiers of Union Citizenship, cit., p. 158.

85 De Witte, F. (2013). Who Funds the Mobile Student? Shedding some Light on the Normative Assumptions Underlying EU Free Movement Law: Commission v Netherlands. Common Market Law Review 50 (1), pp. 203-215, 210. 
of a sufficient legislative or regulatory framework for student mobility in the EU. ${ }^{86}$ The same could be said for the whole of EU citizenship rights, among which the differentiation of separate categories of mobile Union citizens is now rendered even more complex by the apparent pre-eminence of rights derived from residence over those derived from the historical worker status under Art. $45 \mathrm{TFEU}$. The specific treatment of frontier workers and their children in these rulings defines the 'ideal citizen' in an even more restrictive sense than the one identified by Sara Iglesias Sánchez. ${ }^{87}$ If the ideal citizen is generally defined as one who moves to another Member State to pursue an economic activity, the ideal student, from the point of view of a Member State providing funding, is one who moves to another Member State temporarily, in order to return and enrich the first State's employment market. While the general aim of promoting free movement remains, the continuing understanding of free movement and exportable welfare as essentially exchanges between Member States rather than rights associated with EU citizenship across a common territory creates limitations on citizens' right to move across the Union.

A major overhaul of secondary law concerning the free movement of citizens is long overdue. Unfortunately, the current political climate does not seem to indicate any progress on this issue. In the absence of an ambitious legislative reform, it is nevertheless imperative that the differentiation between migrant and frontier workers is curtailed if we are to avoid unacceptable restrictions on the rights granted to Union citizens under Art. 45 TFEU. Of course, a more desirable reform should not only concern students or frontier workers but the concept of EU citizenship itself. However, as Niamh Nic Shuibhne writes, such a change would in reality require a new federal bargain. ${ }^{88}$ In the meantime, she rightly states that 'Union citizenship is overburdened with expectations, both polity-related and rights-related, which it simply cannot deliver'89

\footnotetext{
86 Skovgaard-Petersen, H., There and Back Again, cit., p. 802.

87 Iglesias Sánchez, S. (2017). A Citizenship Right to Stay? The Right Not to Move in a Union Based on Free Movement. In Kochenov, D. ed., EU Citizenship and Federalism, cit., pp. 371-393.

88 Nic Shuibhne, N. (2017). Recasting EU Citizenship as Federal Citizenship: What Are the Implications for the Citizen When the Polity Bargain Is Privileged?. In Kochenov, D. ed., EU Citizenship and Federalism, cit., pp. 147-177, p. 176.

89 Ibid., p. 175.
} 
and this will remain so for as long as such a fundamental political change remains unlikely. However, while the Court tries to strike an appropriate balance between the rights derived from citizenship and Member States' concerns, we must be careful not to weaken those rights which do have a firm footing in the Treaties. 